\title{
Environmental Impact of Casablanca Landfill on Groundwater Quality, Morocco
}

\author{
Driss Smahi, Ahmed Fekri, Ouafa El Hammoumi \\ Laboratory of Geochemistry, Applied Geology and Environment, Faculty of Science Ben M'sick, University Hassan II, \\ Mohammedia-Casablanca, Morocco \\ Email: d_smahi@yahoo.fr
}

Received September 24, 2012; revised October 23, 2012; accepted November 25, 2012

\begin{abstract}
The Casablanca landfill is one among many uncontrolled dumping sites in Morocco with no bottom liner. About 4000 tons/day of solid wastes from mixed urban and industrial origins are placed directly on the fifteen old sandstone quarries. At the site of this landfill, the groundwaters circulate deeply $(<10 \mathrm{~m})$ in the fractured aquiferous quartzites, the site has never been sealed before its opening. The aim of this study is the characterization the groundwater quality around the landfill, to delimit the contaminated zone and the factors controlling the extent of groundwater contamination. To evaluate groundwater pollution due to this landfill, piezometric level and geochemical analyses have been carried out on 19 wells. The results of geochemical analyses show an important qualitative degradation of the groundwater, especially in the parts situated in the down gradient area and in direct proximity to the landfill. In these polluted zones, we have observed the following values: higher than $11 \mathrm{mS} / \mathrm{cm}$ in electric conductivity, $1400 \mathrm{mg} / \mathrm{L}$ in bicarbonates, $275 \mathrm{mg} / \mathrm{L}$ in chemical oxygen demand, 2616 and $100 \mathrm{mg} / \mathrm{L}$ respectively in chlorides and sulfate, $269.5 \mathrm{mg} / \mathrm{L}$ in nitrates, $50-100$ $\mathrm{mg} / \mathrm{L}$ in cadmium, and $40-230 \mu \mathrm{g} / \mathrm{L}$ in chromium. These concentrations widely exceed the standard values for potable and irrigation water. Several determining factors in the evolution of groundwater contamination have been highlighted, such as: depth of the water table, permeability of unsaturated zone and lineaments, effective infiltration, absence of a system for leachate drainage. So, to reduce the pollution risks of the groundwater, it is necessary to set a system of collection, drainage and treatment of landfill leachates and to emplace an impermeable surface at the site of landfill, in order to limit the infiltration of leachate.
\end{abstract}

Keywords: Groundwater Pollution; Landfill Leachate; Uncontrolled Landfill; Lineament; Morocco

\section{Introduction}

The quantity and quality of municipal solid waste depends upon various factors such as population, life style, eating habits, standard of living, the extent and intensification of economical activities, the cultural tradition of the inhabitants, climate [1-5]. The demographical development and the intensification of the economical activities in Morocco, are accompanied by an increase of solid waste production [6-8] with 4.5 millions tons per year of urban wastes. The composition of household waste $[9,10]$, consist mainly of organic matter $(50 \%-70 \%)$, paper $(5 \%$ - $10 \%)$, plastics $(6 \%-8 \%)$, metals $(1 \%-4 \%)$ and glass $(1 \%-2 \%)$. The production of industrial waste is about one million tons per year, with $12.3 \%$ of hazardous waste. This waste is composed mainly by food waste (55\%), parachemical and chemical waste (32\%).

The Casablanca landfill has starting since 1986; it receives the waste from the city of Casablanca and its surroundings, in which the people $(3,616,000$ inhabitants) [11] and life style are continuing to grow. Indeed, the daily quantity of the wastes dumped into the landfill has increased from $2.1 \mathrm{~T}$ in 1989 to $2600 \mathrm{~T}$ in 2000 to more than $3200 \mathrm{~T}$ in 2010 of waste of different categories and from different sources [12]. The site of landfill is considered the largest nationwide, it has no waterproof device or system for collecting landfill leachate, which is estimated daily amount of $1277 \mathrm{~m}^{3} /$ day in 2007 . Because of the urban location of the landfill, this uncontrolled dumping has negative effects that are clearly identified such as nauseous smells, smoke generation, pollution of the water table and the soil $[13,14]$.

This study aims to update the status of knowledge on the front of the pollution of groundwater by landfill leachate; to estimate to what extent the aquifer is polluted and to determine the factors controlling the progress of the pollution front. We will also aim at giving a comparison with other studies already done.

\section{Site Characteristics}

Casablanca has uncontrolled waste dumping within a na- 
tural landfill that is located within one mile of the Mediouna center (Figure 1), in the middle of residential areas. This urban location can constitute a risk for the neighboring population [2,14-16].

The site is composed of 15 quarries, which add up a volume bordering 3 million $\mathrm{m}^{3}$ out of 78 hectares, of which 60 are assigned to the landfill. Nearby passes the main road (P.R.7), which is considered as a high quality axis connecting Casablanca to Marrakech, an intense traffic road [17]. Here, wastes have been landfilled since 1986 that include domestic, industrial and hospital refuse with no preliminary treatment $[13,14]$. Currently, the landfill receives 3,200 tons per day of refuse, which results more than $1300 \mathrm{~m}^{3} /$ day [18] of landfill leachate.

The climate is of semi-arid type with an annual rainfall of $323.5 \mathrm{~mm}$, a mean temperature of $19^{\circ} \mathrm{C}$ and high atmospheric humidity. The dominating wind direction (NorthNorthest) blows from the landfill towards the Mediouna $[14,19]$.

The studied zone, which is a part of the Moroccan coastal Meseta, is formed by a Paleozoic substratum overlaid by Mesozoic and Plioquaternary subtabular beds. Indeed, The primary formations constitute the substratum of the landfill. They are Cambrian and Ordovician marine sediments affetced by the Hercynian Orogeny. They were compressed and their transformation gave rise to Acadian green schist surmounted by quartzite, between psammitic series. They were folded, faulted and tilted. Their reliefs were eroded, peneplained with a well marked surface

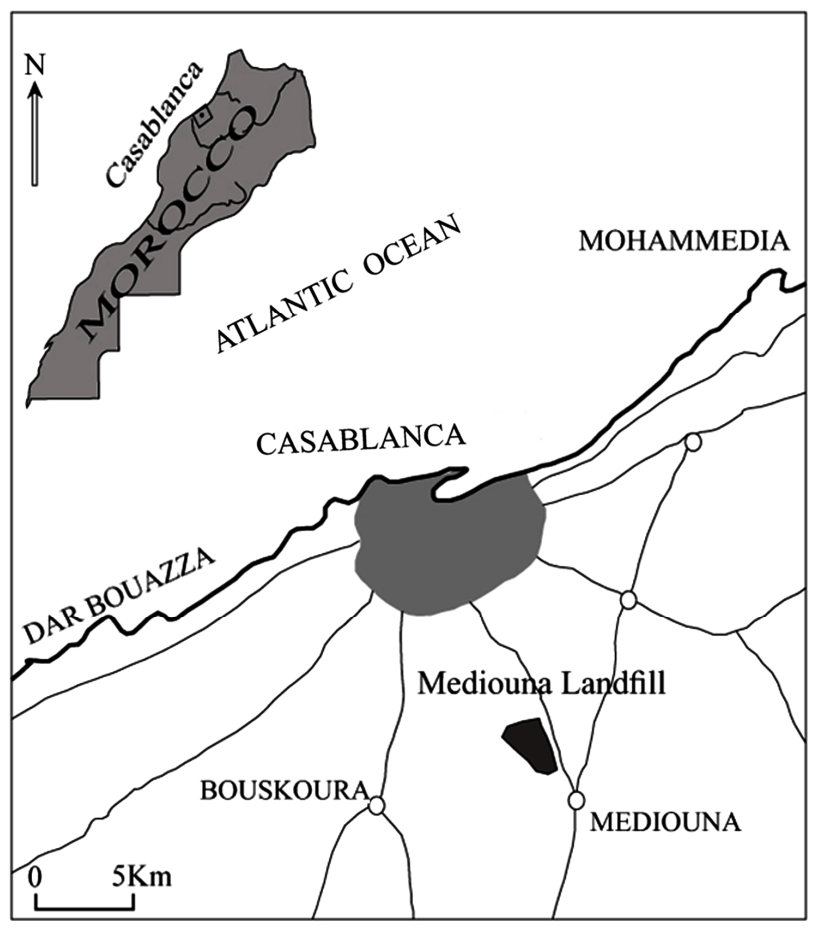

Figure 1. Geographical situation of landfill site. constituting a diastheme [20-23]. The Pliocene higher tertiary sector and the quaternary are also marine formations with lumachellic or conglomerate facies covered by sandstones. Card flayed of Plio-Quaternary shows a change in the nature of the aquifer matrix, the quartzitic facies spend just downstream landfill to the mudstone formations. The bottom of the landfill consisted on fractured aquiferous quartzites [14].

\section{Material and Methods}

The study area was the subject of two sampling campaigns; the first in October 2010 is the period of low tide and the second in April 2011 at high tide. The analyses are carried out on a network of 19 wells surrounding the landfill. The majority of sampled wells are used by neighboring population for daily drinking, irrigation, animal alimentation and for agriculture.

The temperature (T), electrical conductivity (EC) and $\mathrm{pH}$ were measured in situ using a multiparameter conductimeter (USP 645) and pH meter HANNA (HI 9126). The concentration of chloride $\left(\mathrm{Cl}^{-}\right)$, sulfate $\left(\mathrm{SO}_{4}^{2-}\right)$, calcium $\left(\mathrm{Ca}^{2+}\right)$, magnesium $\left(\mathrm{Mg}^{2+}\right)$, carbonates $\left(\mathrm{HCO}_{3}^{-}\right)$, oxydability and chemical oxygen demand (COD), were determined using the volumetric method (AFNOR, 1990). The biochemical oxygen demand $\left(\mathrm{BOD}_{5}\right)$ was measured by BOD meter HANNA (HI 98186). Nitrate $\left(\mathrm{NO}_{3}^{-}\right)$are analysed by colorimetry method using spectrophotometer (Spectronic 20D). The heavy metals (Fe, $\mathrm{Zn}, \mathrm{Pb}, \mathrm{Al}$, $\mathrm{Mn}, \mathrm{Cu}, \mathrm{Cd}, \mathrm{Cr}$ ) were determined using atomic absorption spectrophotometer (Unicam 929 AA Spectrometer).

The piezometric level and thematic maps were gridded using the inverse distance weighted.

\section{Results and Discussion}

\subsection{Piezometric Level Study}

Several measurements were made in December 2011 around the landfill for the establishment of the piezometric map (Figure 2). The overall flow direction of the aquifer is North (from the landfill towards the Atlantic Ocean). Indeed, we observe a bidirectional flow. One from the West with a hydraulic gradient around $2 \%$ indicating bad water circulation. The second from the East with a low hydraulic gradient about $1 \%$. So we have a good flow of groundwater in this area.

The map (Figure 3) show that the small depths of the groundwater table (generally inferior to $16 \mathrm{~m}$ with a minimum of $0 \mathrm{~m}$ ) were observed down gradient of the landfill area. The depths vary between $0 \mathrm{~m}$ downstream of the landfill (spring of AinHallouf) and $10 \mathrm{~m}$ upstream of the landfill. The presence of zero meter piezometric level in the area indicates another potential source of pollution: agricultural and industrial activities. 


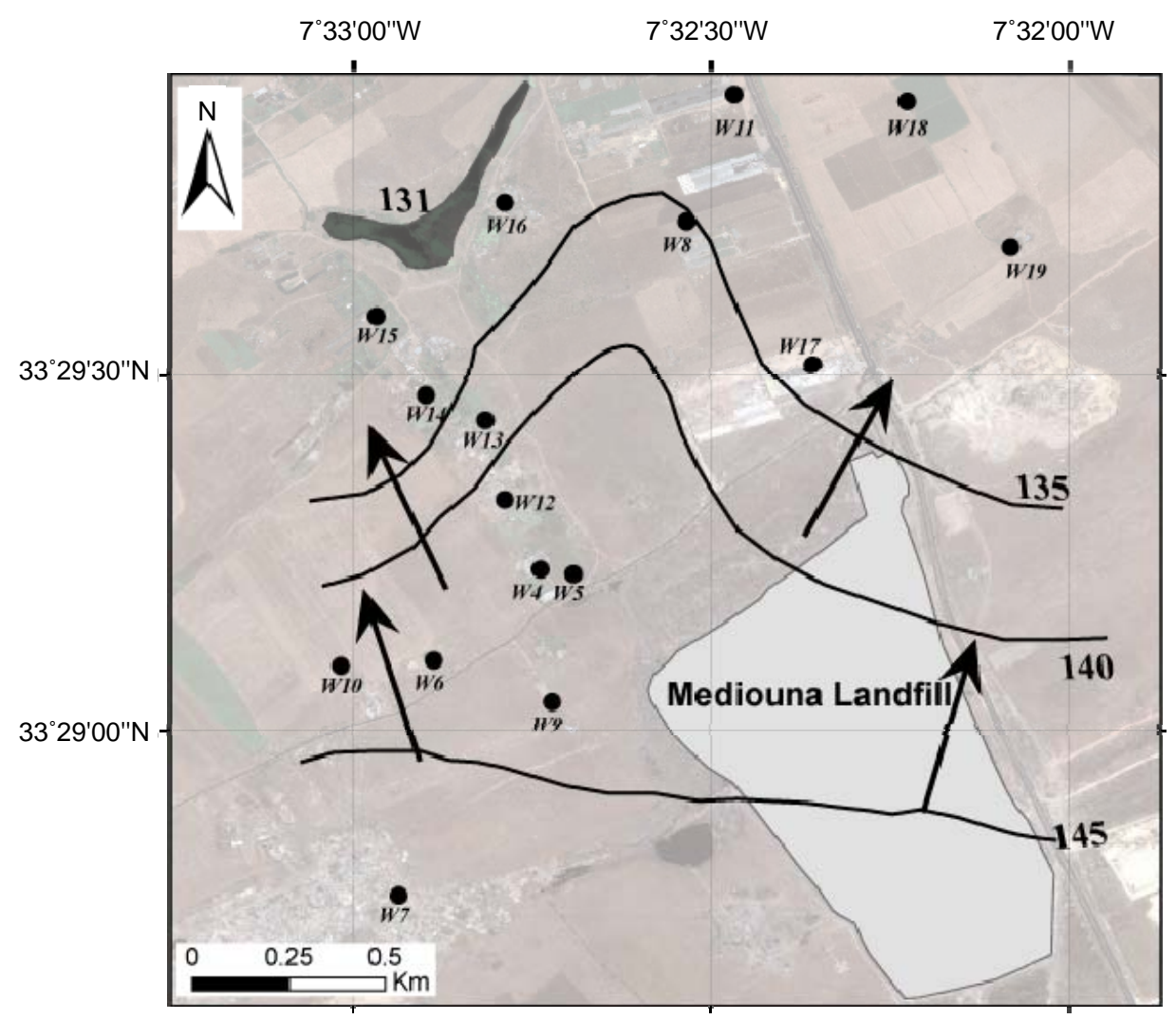

Figure 2. Piezometric level map (December 2011).

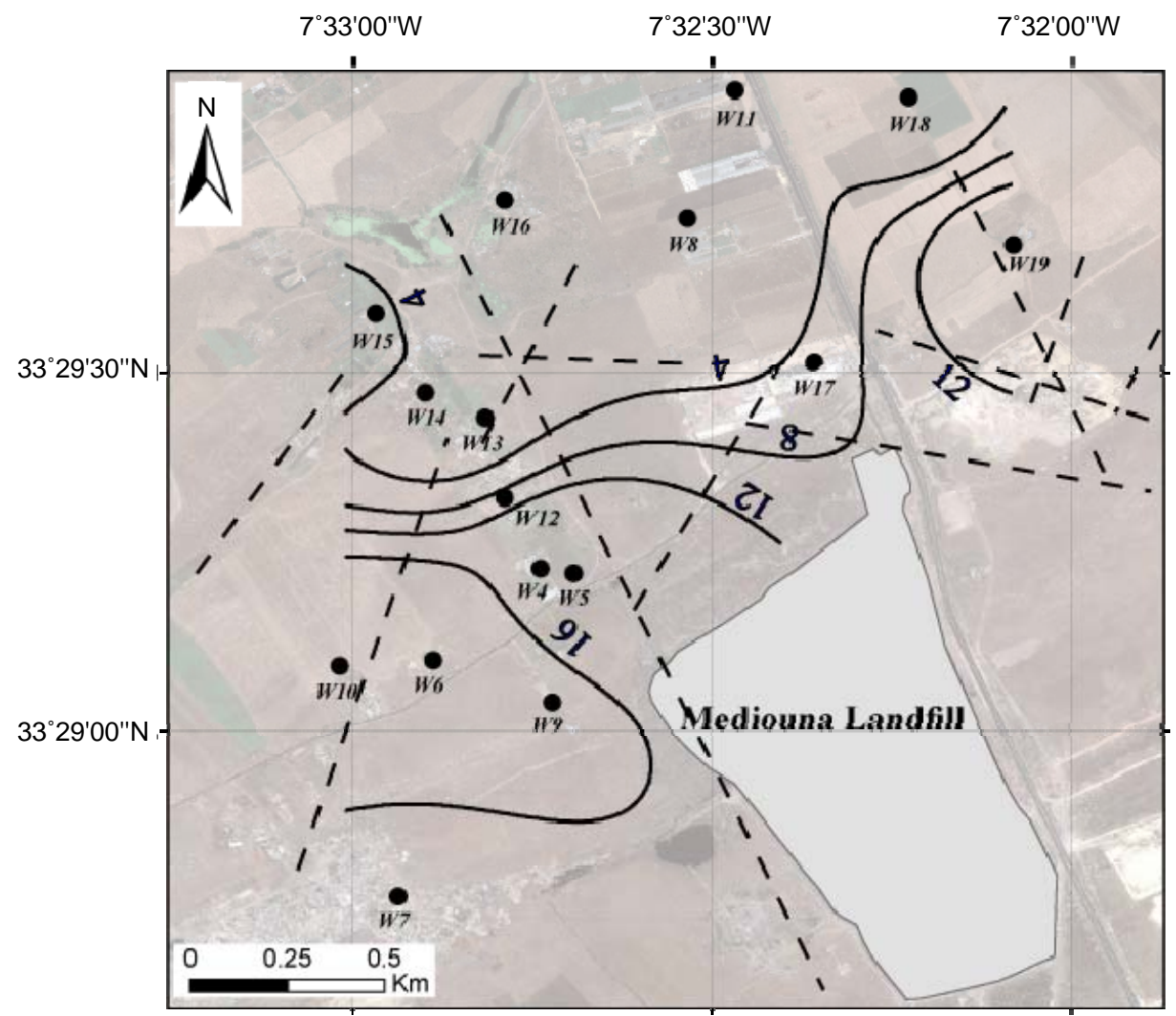

Figure 3. Water table map in meter (December 2011). 


\subsection{Evaluation of the Landfill Leachate Effects}

The landfill leachate is a result of leaching of soluble compounds by the percolation non-uniform and intermittent water through the waste and by bacterial degradation of organic substances [15].

The quantity and quality of leachate depend on the availability of water, weather conditions, waste characteristics, the underlying soils, the degree of fermentation in the landfill, operational procedures, and the coexistence of industrial waste [24-28].

The landfill leachate originating from the Mediouna landfill is highly concentrated (Table 1) with chloride $(5540 \mathrm{mg} / \mathrm{L})$, sulfate $(1320 \mathrm{mg} / \mathrm{L})$ and nitrates $(75 \mathrm{mg} / \mathrm{L})$. It's dissolved organic matter content (COD) is 50,000 $\mathrm{mg} / \mathrm{L}$ while its $\mathrm{BOD}_{5}$ is weak $(34,000 \mathrm{mg} / \mathrm{L})$.

The ratio $\mathrm{BOD}_{5}$ to $\mathrm{COD}$ indicates the degree of biodegradability of the leachate and provides indications regarding the age of a landfill and about biochemical alterations within the landfill. For a young landfill, where biological activity corresponds to the acid phase of anaerobic degradation, the $\mathrm{BOD}_{5} / \mathrm{COD}$ ratio reaches values of 0.85 . It does decrease to a value of 0.05 for other landfills (El Jadida, Rabat, Alger, Belfort) for which active methane production in recorded. For the Casablanca landfill the $\mathrm{BOD}_{5} / \mathrm{COD}$ is indicative of a mature landfill with a ratio of 0.68 . These suggest that leachate from the

Table 1. Chemical composition of the leachate of the Mediouna landfill [19].

\begin{tabular}{cc}
\hline Parameter & Value \\
\hline $\mathrm{EC}(\mu \mathrm{S} / \mathrm{cm})$ & 34,800 \\
$\mathrm{pH}$ & 6.3 \\
$\mathrm{COD}\left(\mathrm{mg} \mathrm{O}_{2} / \mathrm{l}\right)$ & 50,000 \\
$\mathrm{BOD}_{5}(\mathrm{mg} \mathrm{O} / \mathrm{L})$ & 34,000 \\
$\mathrm{HCO}_{3}^{-}(\mathrm{mg} / \mathrm{L})$ & 2250 \\
$\mathrm{NO}_{3}^{-}(\mathrm{mg} / \mathrm{L})$ & 75 \\
$\mathrm{SO}_{4}^{2-}(\mathrm{mg} / \mathrm{L})$ & 1320 \\
$\mathrm{Cl}^{-}(\mathrm{mg} / \mathrm{L})$ & 5540 \\
$\mathrm{Na}^{+}(\mathrm{mg} / \mathrm{L})$ & 3860 \\
$\mathrm{~K}^{+}(\mathrm{mg} / \mathrm{L})$ & 3300 \\
$\mathrm{Ca}^{2+}(\mathrm{mg} / \mathrm{L})$ & 170 \\
$\mathrm{Fe}(\mu \mathrm{g} / \mathrm{L})$ & 1800 \\
$\mathrm{Zn}(\mu \mathrm{g} / \mathrm{L})$ & 3000 \\
$\mathrm{Cu}(\mu \mathrm{g} / \mathrm{L})$ & 1000 \\
$\mathrm{Cr}(\mu \mathrm{g} / \mathrm{L})$ & 750 \\
$\mathrm{~Pb}(\mu \mathrm{g} / \mathrm{L})$ & 360 \\
$\mathrm{Hg}(\mu \mathrm{g} / \mathrm{L})$ & 22 \\
$\mathrm{Mg}(\mu \mathrm{g} / \mathrm{L})$ & 12 \\
\hline
\end{tabular}

Casablanca municipal landfill corresponds to the acid phase of anaerobic. This phase is characterized by a decrease in $\mathrm{pH}$, a acids production and an increase of COD and BOD5 [2,15].

The maps (Figures 4 and 5) show that a high electric conductivity (more than $8 \mathrm{mS} / \mathrm{cm}$ with a maximum exceeding $11 \mathrm{mS} / \mathrm{cm})$, a high chloride content $(2500 \mathrm{mg} / \mathrm{L})$, and a high sulfate concentration $(156 \mathrm{mg} / \mathrm{L})$ are observed for the wells located down gradient and near the landfill.

Also, high metallic concentrations $(0.05-0.1 \mathrm{mg} / \mathrm{L}$ in cadmium and $0.04-0.23 \mathrm{mg} / \mathrm{L}$ in chromium) are observed in these wells.

Such contents of chloride are much higher than the acceptable upper limits suggested by the OMS $(600 \mathrm{mg} / \mathrm{L})$. In fact, this is observed for $37 \%$ of the 19 monitored wells.

The concentration can exceed $2616 \mathrm{mg} / \mathrm{L}$ for chloride and $156 \mathrm{mg} / \mathrm{L}$ for sulfate in the vicinity of the landfill owing to the infiltration of highly salt loaded leachate $\left(\mathrm{CE}=34.8 \mathrm{mS} / \mathrm{cm}, \mathrm{Cl}^{-}=5540 \mathrm{mg} / \mathrm{L}, \mathrm{SO}_{4}^{2-}=1150\right.$ $\mathrm{mg} / \mathrm{L})$.

The distribution of the leachate within the unsaturated zone constitutes a salinity plume near the landfill.

The extension and spreading of this plume are clearly evidenced down gradient of the landfill, as expected from the groundwater main flow direction. This migration of pollutants is favored by:

- Ascent of the water table within the landfill, at the bottom of the quarries (direct contact of groundwater with landfill leachate);

- Low depth of the water table down gradient of the landfill, generally lower than $16 \mathrm{~m}$;

- Absence of drainage network and recovery devices of the leachate that forms within the landfill and reaches soils and groundwater;

- High permeability of quartzites fractures;

- Drainage of the water table from the landfill towards the North.

The salinity is mainly determined by chloride and sulfate ions that are very mobile and constitute non-reactive tracers. The comparison of these results with those of other studies in the Eljadida area [29] and in the Rabat area [8] and in the Belfort region [30], shows that the impact of landfill leachates on the groundwater quality is important, especially for the wells located down gradient and near the landfill. In fact, the Amhoud (1997) data indicate that the electric conductivity and chloride contents of the groundwaters are relatively similar than our values $\left(11 \mathrm{mS} / \mathrm{cm}\right.$ in $\mathrm{EC}$ and $2500 \mathrm{mg} / \mathrm{L}$ in $\left.\mathrm{Cl}^{-}\right)$.

For wells located far from the landfill, high salinity records are related to another source of pollution, agricultural or industrial activities [14]. In fact, the spatiotemporal variations of the chemical elements are connected with the lithological nature of the aquifer, soil nature, 


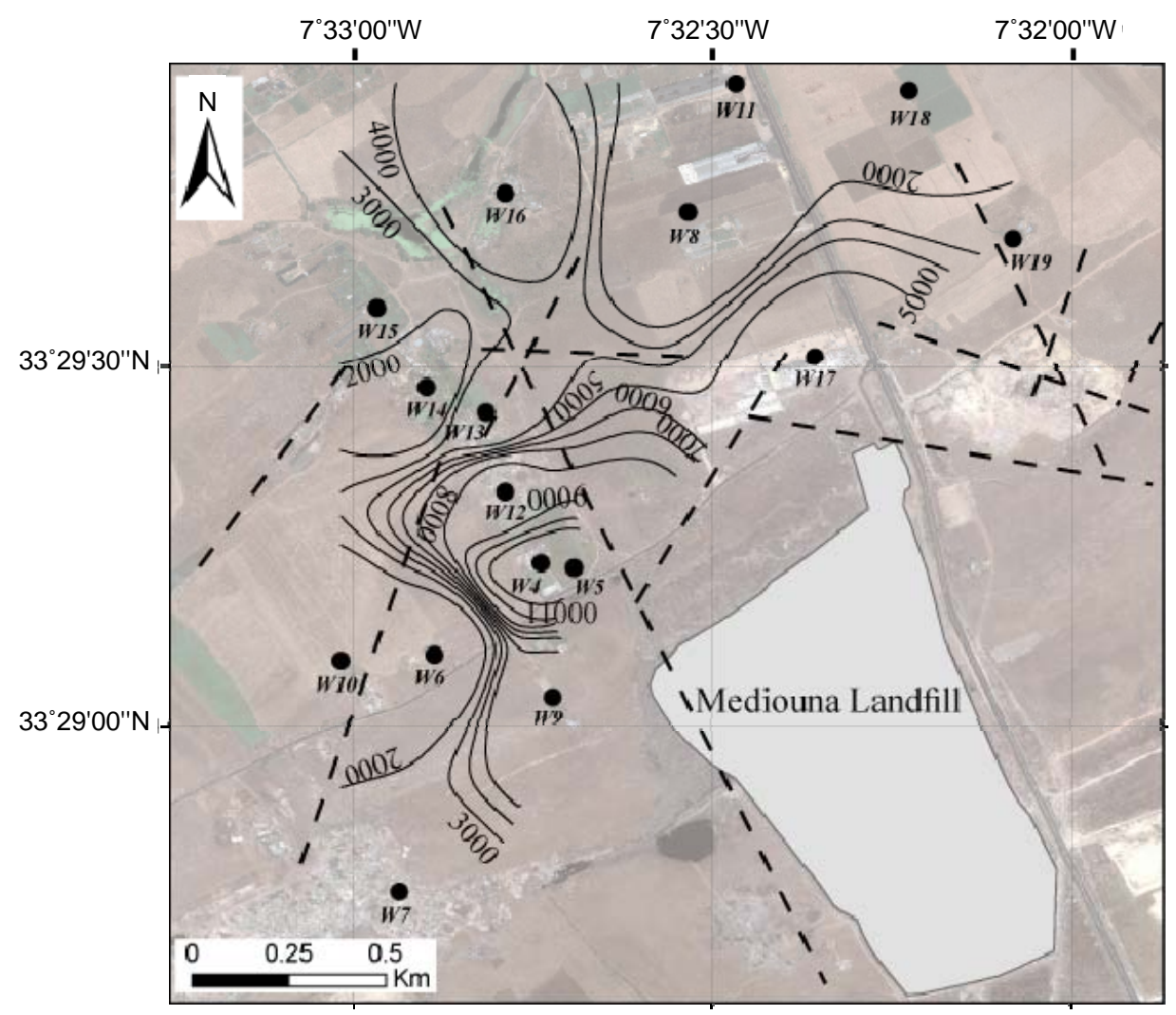

Figure 4. Electric conductivity map in $\mu \mathrm{S} / \mathrm{cm}$ (April 2011).

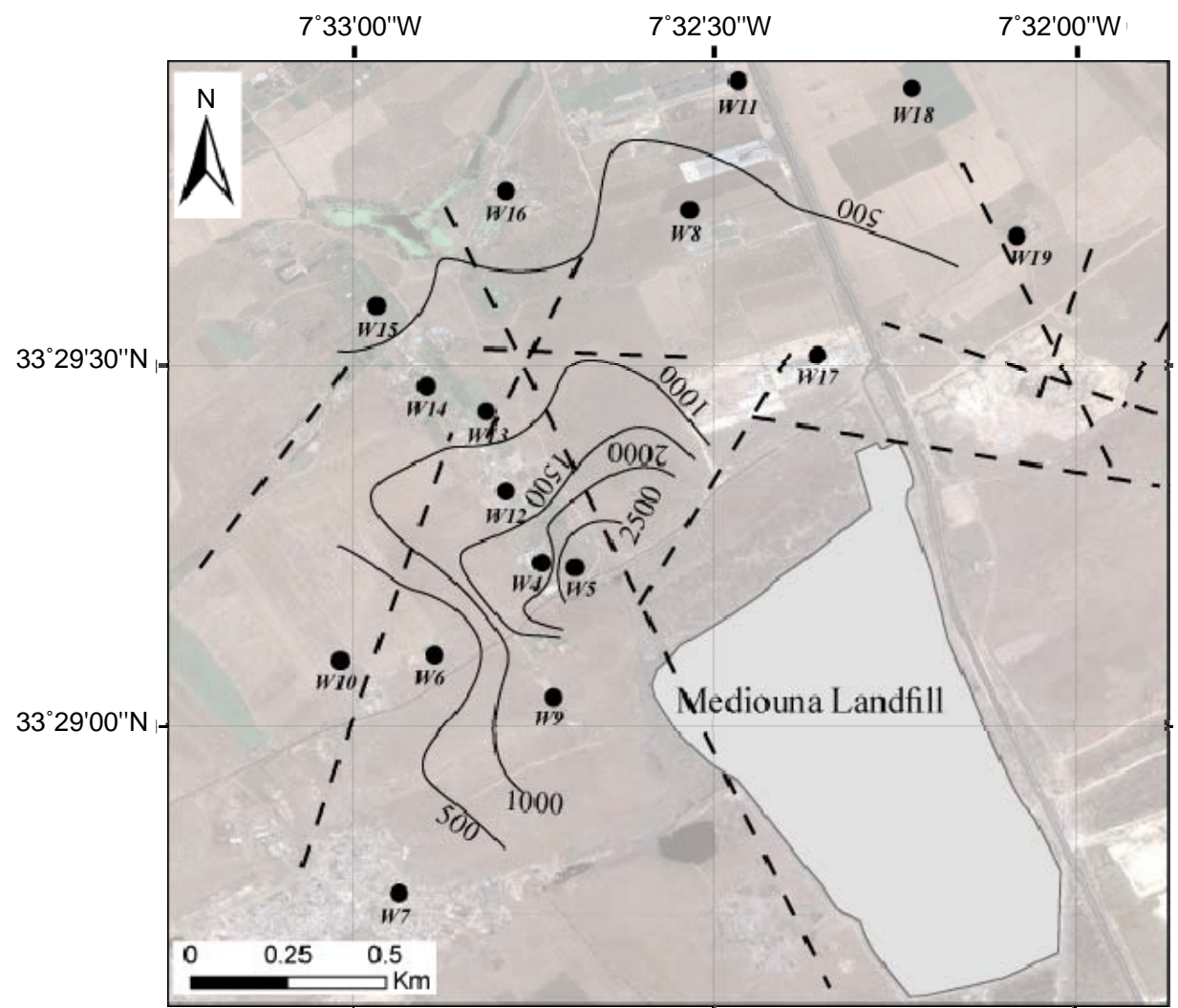

Figure 5. Chloride map in mg/L (April 2011). 
depth of the water level, frequency of the pumping operations, rainfall, nitrogen fertilization, evaporation [13, $14,31]$.

All the monitored wells show nitrate contents exceeding $50 \mathrm{mg} / \mathrm{L}$ [32]. These high concentrations were observed (Figure 6) especially in:

- The areas wich the wells near the habitats (septic tanks);

- The agricultural zones where we observe an excessive use of fertilizers;

- Down gradient of the Casablanca landfill.

The same results were demonstrated in the other studied regions: Morocco [8,29,33-35], Europe [36,37]. In these areas, the principal sources of nitrate contamination are fertilizers and domestic waste waters.

The non-contaminated groundwater generally contains little or no organic matter in semi-arid regions.

However, in wells W4 and W5 located near the landfill (Figure 7), COD contents that can largely exceed 240 $\mathrm{mg} / \mathrm{L}$ are found. This is close to the concentration generally observed for Moroccan waste water [35].

The wells situated down gradient of the landfill display much lower COD content, likely owing to the presence of redox fronts. It could be linked to a distribution of the organic pollution of the landfill, by drainage of the water table. In the studied urban areas where the ground- waters are used for human activities (the case of the public bath in Morocco), some wells contain an important organic matter (oxydability $=35 \mathrm{mgO}_{2} / \mathrm{L}$ ). Such groundwaters must not to be used for domestical activities.

Generally, human activities such as the combustion of fossils fuels, mining and smelting operations, processing and manufacturing industries, waste disposal including dumping, release of domestic sewage, and scrap metal handling are the major source of metals in the environment [38]. Some metals are essential (like Zinc), because they are an integral part of at least one enzyme, and since the primary action of such essential metals is to act as catalyst, only trace amounts are necessary for optimal cellular function [39]. Other metals are toxic, producing

a wide range of effects. As elements, metals are indestructible and therefore have the potential for accumulation in the biological tissues and so become toxic when reaching critical concentrations and induce serious diseases: genetic anomalies and cancers risks (cadmium, arsenic); neurotoxic effects, renal failure (lead, mercury...); cardiac and breathing complications (nickel) [39-42].

The results shown in Table 2 evidence clearly the important metallic load of Casablanca landfill leachate, in comparison with other landfills in the Alger area [43], Rabat region [8], in the Belfort area [30] and in El Jadida area [29]. The measured concentrations show the fol-

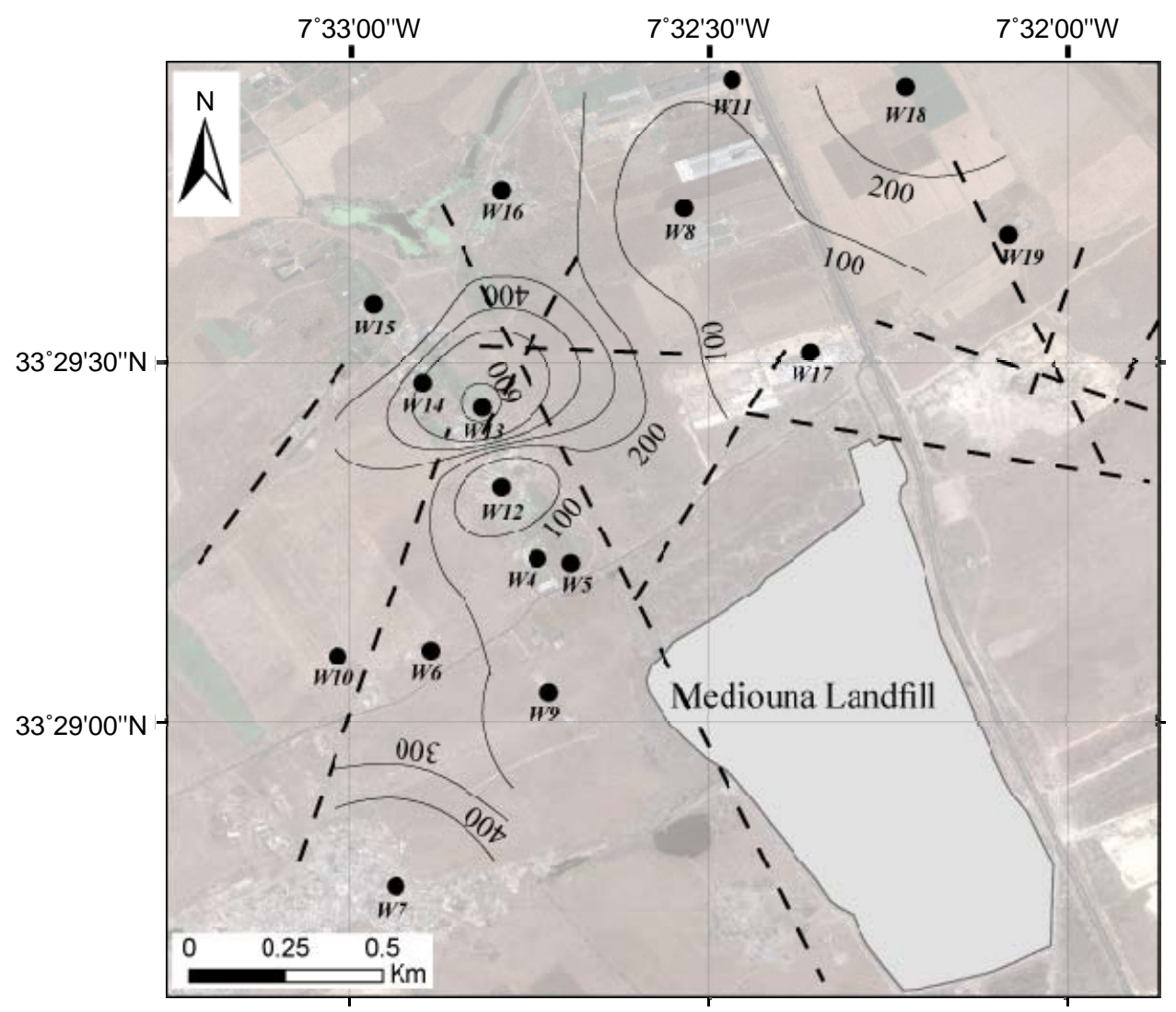

Figure 6. Nitrates map in mg/L (April 2011). 


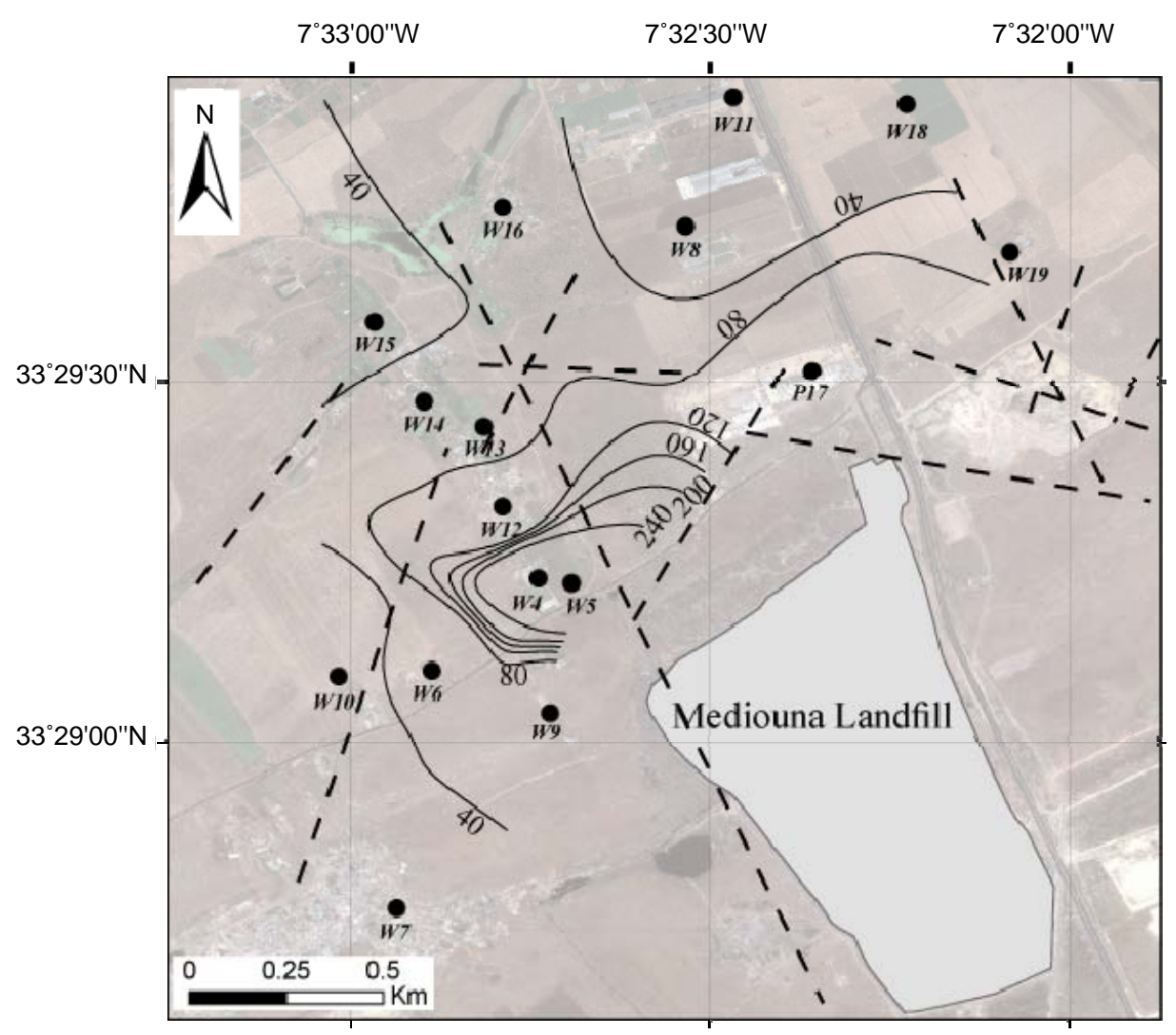

Figure 7. Chemical oxygen demand map in $\mathrm{mg} / \mathrm{L}$.

Table 2. Comparison of metal concentrations of Casablanca landfill leachates (data of 2007) in relation to others national and international landfills.

\begin{tabular}{|c|c|c|c|c|c|c|}
\hline $\begin{array}{l}\text { Concentration of } \\
\text { heavy metals in } \\
\text { leachates }(\mu \mathrm{g} / \mathrm{L})\end{array}$ & $\begin{array}{l}\text { Landfill of } \\
\text { Casablanca } \\
\text { (Morocco) }\end{array}$ & $\begin{array}{l}\text { Landfill of El Jadida } \\
\text { (Morocco) [29] }\end{array}$ & $\begin{array}{l}\text { Landfill of Rabat } \\
\text { (Morocco) [8] }\end{array}$ & $\begin{array}{l}\text { Landfill of Alger } \\
\text { (Algeria) [43] }\end{array}$ & $\begin{array}{l}\text { Landfill of } \\
\text { Etueffont } \\
\text { (France) [30] }\end{array}$ & $\begin{array}{l}\text { Variation of metal } \\
\text { concentrations of urban } \\
\text { landfill leachates [3] }\end{array}$ \\
\hline $\mathrm{Zn}$ & 845 & 747.2 & - & 700 & 740 & $30-1 \times 10^{6}$ \\
\hline $\mathrm{Fe}$ & 18,000 & 24,000 & 23,000 & 12,300 & 2630 & $3 \times 10^{3}-55 \times 10^{5}$ \\
\hline $\mathrm{Cu}$ & 460 & 157.8 & 118 & 450 & 270 & $5-1 \times 10^{4}$ \\
\hline $\mathrm{Mn}$ & 1320 & 1256.72 & 4922 & 400 & - & $30-14 \times 10^{5}$ \\
\hline $\mathrm{Ni}$ & 113.2 & 133.8 & 133.6 & 250 & 210 & $15-13 \times 10^{3}$ \\
\hline $\mathrm{Cr}$ & 150 & 156.33 & 517 & 500 & 270 & $20-15 \times 10^{2}$ \\
\hline $\mathrm{Co}$ & 220 & 208.6 & - & - & 60 & $5-15 \times 10^{2}$ \\
\hline $\mathrm{Cd}$ & 31 & 34 & 8.38 & - & 10 & $0.1-4 \times 10^{2}$ \\
\hline
\end{tabular}

lowing classifications: $\mathrm{Fe}>\mathrm{Mn}>\mathrm{Zn}>\mathrm{Cu}>\mathrm{Pb}$ and $\mathrm{Co}>$ $\mathrm{Cr}>\mathrm{Ni}>\mathrm{Cd}$. The same classifications have been observed for leachates originating from landfills of El Jadida and Rabat (Morocco) and of Alger (Algeria). Generally, the metallic load of studied leachate corresponds to a typical composition of leachate generated by urban landfill, like the other urban landfills, nationally and internationally (Table 2). In fact, the concentrations of metallic elements of the studied leachate are globally similar to other leachates generated by other municipal landfills.

The results of the heavy metal analysis of groundwaters are shown in Table 3. They show that, generally, the undesirable metals $(\mathrm{Fe}, \mathrm{Zn}, \mathrm{Mn}, \mathrm{Cu}$ ) are predominant in relation to the toxic metals $(\mathrm{Cd}, \mathrm{Cr}, \mathrm{Pb}, \mathrm{Al})$. However, the wells (W4, W5, W12, W13, W14 and W17) that are situated in the neighborhood of the landfill present high concentrations in:

- Undesirables metals: $\mathrm{W} 4=0.35, \mathrm{~W} 5=0.36, \mathrm{~W} 12=$ $0.43, \mathrm{~W} 13=0.46, \mathrm{~W} 14=\mathrm{W} 17=0.43$ and $0.32 \mathrm{mg} / \mathrm{L}$ 
Table 3. Comparison of the metal averages of wells with the standards.

\begin{tabular}{|c|c|c|c|c|c|}
\hline Heavy metals $(\mu \mathrm{g} / \mathrm{L})$ & Moroccan standard (MS) [46] & Frensh standard (FS) & Nbr wells $>$ MS & Nbr wells $>$ FS & Leachate $(\mu \mathrm{g} / \mathrm{L})$ \\
\hline $\mathrm{Fe}$ & 300 & 200 & 15 & 19 & 18,000 \\
\hline $\mathrm{Zn}$ & 3000 & 5000 & 0 & 0 & 845 \\
\hline $\mathrm{Pb}$ & 10 & 50 & 19 & 18 & 360 \\
\hline $\mathrm{Al}$ & 200 & 200 & 19 & 19 & \\
\hline $\mathrm{Cu}$ & 2000 & 1000 & 0 & 0 & 460 \\
\hline $\mathrm{Cr}$ & 50 & 50 & 19 & 19 & 150 \\
\hline $\mathrm{Cd}$ & 3 & 5 & 19 & 19 & 31 \\
\hline Mn & 500 & 50 & 3 & 4 & - \\
\hline
\end{tabular}

for iron $=0.14$ and $\mathrm{W} 4=0.14, \mathrm{~W} 5=0.08, \mathrm{~W} 12=$ $0.08, \mathrm{~W} 13=0.15, \mathrm{~W} 14=0.12$ and $\mathrm{W} 17=0.04 \mathrm{mg} / \mathrm{L}$ for copper.

- $\quad$ Toxics metals: $\mathrm{W} 4=0.23, \mathrm{~W} 5=0.19, \mathrm{~W} 12=0.09$, $\mathrm{W} 13=0.17, \mathrm{~W} 14=\mathrm{W} 17=0.12$ and $0.04 \mathrm{mg} / \mathrm{L}$ for chromium and $\mathrm{W} 4=0.05, \mathrm{~W} 5=0.09, \mathrm{~W} 12=0.10$, $\mathrm{W} 13=0.06, \mathrm{~W} 14=0.09$ and $\mathrm{W} 17=0.08 \mathrm{mg} / \mathrm{L}$ for cadmium.

These metallic element concentrations exceed significantly the Moroccan and French standards for potable water (Table 3). These high concentrations are linked to the contamination by the landfill leachates, which are high in heavy metals $[44,45]$. Other factors favor the metallic groundwater contamination $[27,41,43]$ :

- Direct contact between groundwater and leachate from the landfill at the bottom of landfill carries;

- Fracturing and lineaments that constitute the leachate drains;

- The proximity of the water table to surface, since water depths range from $0 \mathrm{~m}$ downstream of the landfill and $10 \mathrm{~m}$ upstream;

- The high permeability of the surrounding geology.

\section{Conclusions}

This investigation strongly suggests that the Casablanca landfill, operational since 1986, shows environmental and health impacts that could be related to observed diseases $(\mathrm{BOD} 5 / \mathrm{COD}=0.68)$, especially due to its location within a residential zone. This landfill produces a highly polluted leachate, which is not, or only weakly biodegradable.

Our hydrochemical study shows that groundwaters in the vicinity of the landfill are characterized by high contents of organic and inorganic chemicals: more than 11 $\mathrm{mS} / \mathrm{cm}$ in electric conductivity, $2500 \mathrm{mg} / \mathrm{L}$ in chloride, $156 \mathrm{mg} / \mathrm{L}$ in sulfate, $0.05-0.1 \mathrm{mg} / \mathrm{L}$ in cadmium and $0.04-0.23 \mathrm{mg} / \mathrm{L}$ in chromium. The main pollution source is linked to the infiltration of leachate that conveys a strong polluting load and to the direct contact of the leachate with waters of the aquifer in the landfill carriers.
This groundwater pollution and its distribution in the unsaturated zone are favored by: low depth of water table, high soil permeability, fracturation of aquifer matrix, absence of drainage systems of the leachate, direct contact of groundwaters with leachate at the bottom of landfill carriers, semi-arid climate.

The effect of other potential sources of groundwater pollution has been shown: septic tanks, excessive use of fertilizers in agriculture practice and industrial activities.

The use of mathematical modeling investigations, should allow better constraint of groundwater dynamics as related to climate variations, leachate contamination and geology.

So as to palliate to the pollution risks of the groundwater, it is necessary to:

- stop immediately to dump wastes in this urban landfill;

- set a system of collection, treatment and drainage of landfill leachates;

- set an impermeable surface at the site of landfill in order to limit the infiltration of leachates and to avoid the contamination of groundwaters;

- control the groundwater quality and survey its evolution (especially the metallic elements) in time and in space, by choosing a representative network of wells.

A particular attention should be paid to the wells situated down gradient of the landfill and in the direction of groundwaters flow.

\section{REFERENCES}

[1] M. Djouka, "The Problem of Solid Wastein Abidjan," Techniques, Sciences et Méthodes-L'Eau 5, 1988, pp. 285-290.

[2] C. Desachy, "The Wastein 1994," Techniques, Sciences et Méthodes-L'Eau 11, 1994, pp. 603-609.

[3] T. H. Christensen, R. Kjeidsen, P. L. Bjerg, D. L. Jensen, J. Christensen, A. Bauna, H. J. Albrechtsen and G. Heron, "Biogeochemistry of Landfill Leachate Plumes," Application Geochemistry, Vol. 16, No. 7-8, 2001, pp. 659-718. doi:10.1016/S0883-2927(00)00082-2 
[4] P. T. Williams, "Waste Treatment and Disposal," 2nd Edition, John Wiley \& Sons, Hoboken, 2005. doi:10.1002/0470012668

[5] U. K. Singh, M. Kumar, R. Chuhan, P. K. Jha, A. L. Ramanathan and V. Subramanian, "Assessment of the Impact of Landfill on Groundwater Quality: A Case Study of the Pirana Site in Western India," Environmental Monitoring and Assessment, Vol. 141, 2008, pp. 390-321. doi:10.1007/s10661-007-9897-6

[6] A. C. Bennani, "Composting: Assessment and Prospects forActionat the National Level, Morocco," Technique, Sciences et Méthodes-L'Eau 5, 1984, pp. 285-290.

[7] E. M. Naifar, "The current situation of Household Waste Disposal of Rabat. Study of the Impact of Akrach landfill leachate on the Environment," Thesis, University Rabat, Rabat, 1996.

[8] S. Amhoud, "Contributions of Geology and Hydrogeology the Study of the Impact of the Akrech Landfill on Water Resources," Thesis, University of Rabat, Rabat, 1997.

[9] A. Ajir, "Solid Waste Management in Morocco: Problems and Development Approach," Proceedings of International Symposium on Environmental Pollution Control and Waste Management, Tunis, 7-10 January 2002, pp. 740747.

[10] H. Chouaouta, "Regional Plan of Waste Management, Tanger-Tétouan," MATEE et GTZ, Projet Gestion de l'Environnement, 2002.

[11] RGPH, "General Census of Population and Housing," 2004.

[12] A. Ajir, "Solid Waste Management in Morocco," National Household Waste Program, 1st Expo Andalusia, 2009.

[13] General Directorate of Hydraulics, "Protection of Chaouia Quartzite Aquifer Downstream of the Lissasfa landfill," 1991.

[14] A. Fekri, "Impact de la Décharge de Médiouna sur les Ressources en Eaux Souterraines," Thesis, University Hassan II Mohammedia, Casablanca, 2007.

[15] F. Ozanne, "The Landfill Leachates, Point of Knowledge 1990," L'Eau: Techniques Sciences et Méthodes Juin, 1990, pp. 289-312.

[16] M. O. Rivett, D. N. Lerner and J. W. Liyod, "Chlorinated Solvents in UKAquifers," Journal of Water and Management, Vol. 4, No. 3, 1990, pp. 242-250. doi:10.1111/j.1747-6593.1990.tb01385.x

[17] A. Fekri, B. El Mansouri, O. El Hammoumi and C. Marrakchi, "Impact of Casablanca Municipal Landfill on Groundwater Resources," International Water Technology Journal, Vol. 3, 2012, pp. 210-216.

[18] H. Chichaoui, "Waste Financing, Case of Casablanca," Thesis, l'ISCAE, Morocco, 2008.

[19] ECOMED, "The Realization and Operation of a Controlled Landfillin Casablanca and Rehabilitation of Current Mediouna Landfill," Mémoire Technique Nouvelle Décharge, Rapport Inédit, Vol. 2B, 2007.

[20] J. Destombes and A. Jeannette, "The Realization and Operation of a Controlled Landfill in Casablanca and
Rehabilitation of Current Mediouna Landfill," Notes et Mémoires du Service Géologique du Maroc, No. 130, 1956.

[21] A. Piqué, "Geology of Morocco. Domains Regional and Structural Evolution," PUMAG Edition, Marrakech, 1994.

[22] M. Ouadia, "Plio-Quaternary Formations in the Western Meseta of Morocco between Casablanca and Safi: Geomorphology, Sedimentology, Quaternary Paleoenvironments and Current Developments," Thesis, University Rabat, Rabat, 1998.

[23] A. El Attari, "Etude Lithostratigraphique et Tectonique du Paléozoïque du Môle Côtier (Meseta Occidentale, Maroc)," Thesis, University Rabat, Rabat, 2001.

[24] A. Navarro, D. Bernard and N. Millot, "Les Problèmes de Pollution par les Lixiviats de Décharge," Techniques, Sciences et Méthodes-L'Eau 3, 1988, pp. 541-545.

[25] J. M. Blanchard, A. Navarro, P. H. Revin, J. Cyclewsky, S. Voyars and G. Pillard, "Les Mâchefers d'Incinération d'Ordures Ménagères II. Utilisation en Traitement des Lixiviats de Décharge," Techniques, Sciences et Méthodes-L'Eau 3, 1989, pp. 133-140.

[26] G. Leclerc and A. Bonneau, "La Lixiviation: Source, Composition et Atténuation," Eau du Québec, Vol. 15, No. 1, 1989, pp. 37-45.

[27] D. N. Lerner and J. H. Tellam, "The Protection of Urban Groundwater from Pollution," Water and Environment Management, Vol. 6, No. 1, 1992, pp. 28-37. doi:10.1111/j.1747-6593.1992.tb00735.x

[28] M. El Fadel, A. N. Findikakis and J. O. Leckie, "Numerical Modeling of Generation and Transport of Gaz and Heat in Sanitary Landfills. II. Model Application," Waste Management and Research, Vol. 14, No. 6, 1996, pp. 537-551.

[29] A. Chofqi, A. Younsi, E. K. Lhadi, J. Mania, J. Mudry and A. Veron, "Environmental Impact of an Urban Landfill on a Coastal Aquifer (El Jadida, Morocco)," Journal of African Earth Sciences, Vol. 39, No. 3-5, 2004, pp. 509-516. doi:10.1016/j.jafrearsci.2004.07.013

[30] H. Khattabi, "The Interests of Study of Hydro-Geological and Hydrobiological Settings for Understanding Operation of Landfill Leachate Treatment of Etueffont (Belfort, France)," Thesis, University Franche Comté, Besançon, 2002.

[31] A. Marjoua, P. Olive and C. Jusserand, "The Origins of Salts in the Chaouia Aquifer Coast (Morocco)," Hydrochemistry, IAHS Publishing No. 244, 1997.

[32] OMS, "Guidelines for Drinking-Water Quality," Geneva, 1993.

[33] H. Guessir, "Study of the Impact of Irrigation on the Raw Wastewater on the Physico-Chemical Quality of Soiland Groundwater, Sidi Bennour Region," Thesis, University El Jadida, El Jadida, 1995.

[34] E. K. Lhadi, M. Mountadar, A. Younsi, G. Martin and J. Morvan, "Nitrate Pollution of Groundwater Nearshore, El Jadida (Morocco)," Journal of hydrogeology, Vol. 3, 1996, pp. 21-33.

[35] H. Tazi, "Solid Wastes: Study of Environmental Impact 
Assessment (Land, Groundwater) and Treatment by Composting," Thesis, University El Jadida, El Jadida, 2001.

[36] M. E. Exner, R. F. Spallding and C. W. Lindeau, "Groundwater Contamination and Well Construction in Southeast Nebraska," Grounwater, Vol. 23, No. 1, 1985, pp. 26-34. doi:10.1111/j.1745-6584.1985.tb02776.x

[37] A. Baun, S. D. Jensen, L. Bjerg, T. H. Christensen and N. Nyholm, "Toxicity of Organic Chemical Pollution in Groundwater down Gradient of a Landfill (Grindsted, Denmark)," Environmental and Technology, Vol. 34, 2000, pp. 647-1652.

[38] M. A. Allus, "Thallium and Trace Metals as Pollutants: Chemometric Studies," Edition Dar Al Jamahiriya for Publishing, 1990.

[39] M. G. Miquel, "Effects of Heavy Metals in the Environment and Health," Tome I, 2001.

[40] G. DeKnudt and D. Leonard, "Cytogenic Investigations on Leucocytes of Workers from a Cadmium Plant," Environmental Physiology \& Biochemistry, Vol. 5, 1975, pp. 319-327.

[41] R. D. Cameron and F. A. Koch, "Toxicity of Landfill
Leachates," Journal of Water, Vol. 52, 1980, pp. 760769.

[42] G. Blanchard, "Aspect of the Behavior of Organo-Metals and Metals in the Environment: Study of Particular derivatives Lead," Thesis, University of Rennes, Rennes, 1982.

[43] R. Kerbachi and M. Belkacemi, "Characterization and Evolution of the Landfill Leachate of Oued Smar, Alger," Techniques, Sciences et Méthodes-L'Eau 11, 1994, pp. 615-618.

[44] S. C. Harpers, R. Manharan, D. S. Mavinic and C. W. Randall, "Chromium and Nickel Toxicity during the Biotreatment of High Ammonia Landfill Leachate," Water Environment Research, Vol. 68, No. 1, 1996, pp. 19-24. doi:10.2175/106143096X127172

[45] D. L. Jensen, A. Ledin and T. H. Christensen, "Speciation of Heavy Metals in Landfill-Leachate Polluted Groundwater," Water Research, Vol. 33, No. 11, 1999, pp. 2642-2650. doi:10.1016/S0043-1354(98)00486-2

[46] ONEP, "Standard Moroccan of Water Quality for Human Consumption,” ONEP Edition, 1993. 